\title{
EVALUASI POSTUR KERJA DAN KELUHAN MUSKOLOSKELETAL PADA PEKERJA INSTALASI FARMASI
}

\author{
Kun Istighfaniar dan Mulyono \\ Departemen Keselamatan dan Kesehatan Kerja \\ Fakultas Kesehatan Masyarakat Universitas Airlangga \\ Email: kun.istighfaniarh@gmail.com
}

\begin{abstract}
Pharmaceuthical department is one of many department in RSUD Kota Madiun which serve hundreds of patients everyday. Workers on pharmacuthical department has been found having unnatural working posture on their work process, where many workers tend to complain about having low back pain problems. One of suspected problem is unnatural working posture. Unergonomic position, repetitive works, sit for long periods were few of ergonomics problem which occurred everyday. This research aimed to identify work posture and musculoskeletal complaint on pharmaceuthical department workers. This research used cross sectional approach, with population sample were all worker on pharmaceuthical department RSUD Kota Madiun and there are eight people in total. Primary data on this research collected using questionnaires, Body Mass Index measurements, interviews, and observations. Collected data from questionnaires, interview, and Body Mass Index measurements were processed, and the processed data will be analyzed using qualitatif methods of deep interview. The result showed most of worker were having high riks of having musculoskeletal problem based on RULA and REBA evaluation. Most of musculoskeletal complaints were located on their waist, hip, upper neck an lower neck. Hospital should give the workers egonomical training so that workers could avoid having unergonomical posture which lead to musculoskeletal problems. Workers should doing more often aerobic exercise.
\end{abstract}

Keywords: muscoloskeletal complaint, work posture

\begin{abstract}
ABSTRAK
Instalasi Farmasi adalah salah satu poli kesehatan di salah satu RSUD kota Madiun yang setiap harinya melayani ratusan pasien dari dalam kota. Pekerja pada poli instalasi farmasi ditemukan sikap kerja yang tidak alamiah dalam proses pekerjaanya, di mana pekerja mengeluh nyeri pada bagian punggung. Salah satu permasalahan yang diduga sebagai masalah adalah sikap kerja yang tidak alamiah. Posisi tidak ergonomis, pekerjaan yang berulang, duduk dalam waktu lama merupakan beberapa masalah ergonomi sehari-hari yang dilakukan. Penelitian ini bertujuan mengindentifikasi postur kerja dan keluhan muskoloskeletal pada pekerja Instalasi Farmasi. Penelitian menggunakan pendekatan cross sectional, dengan populasi sampel seluruh pekerja instalasi farmasi RSUD Kota Madiun sejumlah delapan orang. Pengumpulan data primer pada penelitian ini menggunakan kuesioner, pengukuran Indeks Massa Tubuh, wawancara, dan observasi. Data yang didapatkan dari kuesioner, wawancara dan data hasil pengukuran kemudian diolah dan data yang telah diolah selanjutnya dianalisis dengan menggunakan metode kualitatif deep interview. Hasil penelitian menunjukkan penilaian postur kerja berdasarkan metode REBA dan RULA mayoritas memiliki level risiko yang tinggi. Keluhan muskoloskeletal yang sering terjadi pada pekerja terdapat pada bagian pinggang, pinggul, leher bagian bawah dan bagian atas. Instansi direkomendasikan untuk memberikan pelatihan tentang ergonomi kerja sehingga dalam kesehariannya pekerja dapat menghindari kesalahan postur kerja, pekerja dianjurkan olah raga secara teratur terutama olah raga aerobik.
\end{abstract}

Kata kunci: keluhan muskoloskeletal, postur kerja

\section{PENDAHULUAN}

Gangguan sistem muskoloskeletal merupakan penyebab utama ketidakhadiran pekerja. Gangguan Sistem muskoloskeletal membuat sistem kesehatan masyarakat kehilangan dana yang sangat besar.

Sekitar setengah dari kasus penyakit akibat kerja berdasarkan The Labour Force Survey (LFS) U.K (2014), adalah musculoskeletal disorders. Lebih dari 500.000 kasus MSDs terjadi dari total 1.200.000 kasus penyakit akibat kerja. Sebagian besar kasus terjadi pada pekerja konstruksi, pekerja pengiriman barang dan petugas kesehatan (Buckley, 2014).

Menurut data Biro Statistik Departemen Tenaga Kerja Amerika (2001), dalam WHO (2003), pada periode tahun 1996-1998 terdapat 4.390.000 kasus penyakit akibat kerja yang dilaporkan, sekitar 64\% diantaranya adalah gangguan yang berhubungan dengan faktor risiko ergonomi. OSHA (2000), 
menyatakan sekitar 34\% dari total hari kerja yang hilang karena cedera dan sakit yang diakibatkan oleh Musculoskeletal Disorders (MSDs) sehingga memerlukan biaya kompensasi sebesar 15 sampai 20 miliar dolar US.

Berdasarkan data Dinas Kesehatan Tahun 2007 terdapat 500.640 kasus dan pada Tahun 2008 terdapat kasus terlapor terkait gangguan muskoloskeltal di Indonesia. Hasil riset Dinas Kesehatan Tahun 2013 prevalensi gangguan muskoloskeletal pada perempuan $(27,5 \%)$ lebih tinggi dari pada laki-laki $(21,8 \%)$.

Menurut journal medicine di Inggris, 180 juta waktu kerja terbuang akibat sakit pinggang, yang disebabkan karena duduk di kursi dengan standar kelayakan yang tidak cukup baik. Disebutkan juga bahwa Low Back Pain (LBP) merupakan keluhan kesehatan nomor dua pada manusia setelah influenza.

Berdasarkan survey data awal di Rumah Sakit Umum Daerah Madiun sebagian pekerja mengeluhkan adanya nyeri di punggung bagian bawah. Masalah nyeri punggung bawah yang timbul akibat duduk lama menjadi fenomena yang sering terjadi saat ini. Kebanyakan orang dewasa mengalami nyeri punggung bawah karena masalah duduk yang terjadi pada mereka yang bekerja atau yang aktivitasnya lebih banyak dilakukan dengan duduk. Duduk lama dengan posisi yang salah dapat menyebabkan otot-otot punggung menjadi tegang dan dapat merusak jaringan lunak sekitarnya. Bila keadaan ini berlanjut, akan menyebabkan penekanan pada bantalan saraf tulang belakang yang mengakibatkan hernia nukleus pulposus.

RSUD Kota Madiun yang berlokasi di Jalan Campursari No.12b Madiun adalah Rumah Sakit Umum Pemerintah dengan kelas C. Instalasi Farmasi adalah salah satu poli kesehatan di salah satu RSUD kota Madiun yang setiap harinya melayani ratusan pasien dari dalam kota. Pekerja pada poli instalasi farmasi ditemukan sikap kerja yang tidak alamiah dalam proses kerjanya, dimana pekerja mengeluh nyeri pada bagian otot tulang belakang.

Salah satu permasalahan yang sering terjadi adalah pada sikap kerja yang tidak alamiah. Posisi tidak ergonomis, pekerjaan yang berulang, duduk dalam waktu lama merupakan beberapa masalah ergonomi sehari-hari yang dilakukan di RSUD Kota Madiun. Beberapa contoh masalah ergonomi yang dapat dijumpai pada proses kerja di instalasi farmasi RSUD Kota Madiun yang dapat dijumpai adalah pada proses pelayanan obat pasien para pekerja harus berulang-ulang melakukan proses duduk, berdiri dan jongkok untuk melayani pengambilan obat, dan terkadang duduk dalam waktu lama. Dampak yang muncul dan dialami oleh pekerja adalah adanya keluhan Muscoloskeletal Disorder.

Berdasarkan latar belakang dan identifikasi masalah, penelitian ini ingin mengetahui "bagaimana distribusi frekuensi postur kerja dan keluhan muskoloskeletal pada pekerja Instalasi Farmasi di RSUD Kota Madiun”.

\section{METODE}

Penelitian ini bersifat observasional deskriptif dengan pendekatan cross sectional.

Populasi penelitian adalah seluruh pekerja di Instalasi Farmasi RSUD Kota Madiun yang berjumlah 8 orang. Penelitian dilakukan pada bulan Februari 2015. Lokasi penelitian bertempat di Jalan Campursari No. 12b Kota Madiun.

Variabel yang diteliti pada penelitian ini adalah postur kerja dan keluhan muskoloskeletal. Postur kerja dilakukan pengukuran dengan metode REBA (Rapid Entire Body Assessment) dan metode RULA (Rapid Upper Limb Assessment). Keluhan muskoloskeletal dilakukan pengukuran dengan menggunakan Nordic Body Map.

Pengumpulan data primer pada penelitian ini menggunakan kuesioner, pengukuran IMT, wawancara, dan observasi. Kuesioner diberikan kepada responden yaitu pekerja Instalasi Farmasi RSUD Kota Madiun. Pengukuran IMT digunakan untuk melihat status gizi dan kuesioner digunakan untuk mengidentifikasi keluhan nyeri otot yang dirasakan oleh pekerja serta untuk memperoleh informasi penunjang yang berhubungan dengan karakteristik responden. Sedangkan, observasi dan wawancara dilakukan untuk mengidentifikasi dan menilai sikap tubuh pada Instalasi Farmasi RSUD Kota Madiun serta untuk mendapatkan data dari responden.

Berdasarkan data yang diperlukan, maka peneliti membutuhkan instrumen untuk mendukung memperoleh data dari responden. Adapun instrumen pengumpulan data yang digunakan dalam penelitian adalah kuesioner, lembar Nordic Body Map, Lembar penilaian REBA, Lembar Penilaian RULA, Lembar observasi pengukuran IMT, kamera.

Pengolahan data hasil kuesioner yang terkumpul dilakukan dengan mengklasifikasikan variable-variabel yang akan diteliti. Adapun tahapan pengolahan data yang akan dilakukan 
adalah sebagai berikut: Coding adalah kegiatan meng klasifikasikan data dan memberi kode sesuai dengan tujuan dikumpulkannya data. Pemberian kode disesuaikan dengan definisi operasional pada penelitian untuk memudahkan dalam analisis data. Editing dilakukan sebelum proses pemasukan data. Kuesioner diperiksa untuk meyakinkan bahwa setiap pertanyaan telah diberi jawaban. Data entry yaitu kegiatan memasukan data atau input data ke sistem computer. Cleaning adalah kegiatan mengecek ulang data yang telah dimasukkan untuk mengantisipasi adanya kesalahan

Untuk metode REBA dan RULA yaitu mengamati pekerjaan yang dianalisis dan mengambil gambar responden dalam posisi kerjanya, menghitung sudut antara posisi kerja dan postur normal, mengisi skoring untuk setiap posisi kerja pada lembar penilaian REBA dan RULA, dan yang terakhir menghitung skor REBA dan RULA.

\section{HASIL}

\section{Gambaran Umum}

Sejarah singkat RSUD Kota Madiun dimulai dengan peresmian pada tanggal 20 April 2004 oleh Walikota Madiun saat itu, yaitu Bapak Drs. Ahmad Ali. Pada saat awal beroperasi di bawah pimpinan Ibu dr. Agung Sulistya Wardani, jumlah tempat tidur adalah 39 TT yang terbagi menjadi Ruang Dewasa, Ruang Anak dan Ruang Kebidanan. Tenaga yang ada juga masih terbatas hanya 23 orang. Demikian juga sarana dan prasarana masih kurang sehingga pelayanan kesehatan yang diberikan juga masih terbatas. Pada tahun 2005, RSUD mulai membenahi sarana dan prasarana yang ada dan diperlukan untuk meningkatkan pelayanan kesehatan di RSUD dengan mengusulkan kegiatan pembangunan gedung Rawat Inap Anggrek untuk menambah kebutuhan Ruang Rawat Inap dan kegiatan pembangunan gedung Rawat Inap Anggrek ini terealisasi pada tahun 2006 bersamaan dengan kegiatan pembangunan pagar tembok yang mengelilingi RSUD.

Lokasi RSUD kota Madiun terletak di jalan Campursari no.12B Madiun. Lokasi tersebut sangat strategis karena masih di wilayah perkotaan dan dapat diakses melalui kendaraan umum serta secara geografis sangat strategis bagi masyarakat. RSUD Kota Madiun menempati areal seluas $45.000 \mathrm{~m}^{2}$ dengan luas bangunan rumah sakit $5181 \mathrm{~m} 2$. Jenis Pelayanan yang ada saat ini adalah Instalasi Rawat
Jalan (Klinik Umum, Klinik Obgyn, Klinik Bedah, Klinik Mata, Klinik Penyakit Dalam, Klinik Gigi, Klinik Anak dan Klinik Syaraf), Instalasi Rawat Inap (R. Dewasa, R. Anak, R. Bersalin, R. VIP), Unit Gawat Darurat, Unit Penunjang (Instalasi Bedah Sentral, Instalasi Farmasi, Instalasi Gizi, Instalasi Laboratorium, Instalasi Radiologi dan Instalasi Pemeliharaan Sarana).

Di dalam Instalasi Farmasi sendiri terdapat 4 bagian koordinasi kerja yaitu administrasi, pergudangan, pelayanan rawat inap dan pelayanan rawat jalan. Administrasi memiliki tugas untuk membuat data laporan tentang obat-obatan yang masuk dan keluar, pergudangan bertugas untuk mengambil barang serta obat-obatan dari gudang utama kemudian mensortir kotak obat sesuai dengan list. Pelayanan rawat inap bertugas melayani permintaan obat untuk poliklinik rawat inap, pelayanan rawat jalan melayani resep pasien untuk dibawa pulang. Terdapat 8 karyawan pada instalasi farmasi dan setiap bagian pada instalasi farmasi memiliki 2 orang pekerja.

Penilaian postur kerja dilakukan dengan menggunakan dua metode yaitu dengan yang pertama dengan menggunakan metode REBA dan kedua menggunakan metode RULA. Metode REBA digunakan untuk memperoleh hasil penilaian dari sudut posisi badan, leher, kaki, pergelangan tangan, lengan bawah dan lengan atas dengan posisi pekerjaan dilakukan dengan berdiri. Metode RULA digunakan untuk memperoleh hasil penilaian dari posisi lengan atas, lengan bawah, pergelangan tangan, posisi leher, posisi badan, dan kaki pada pekerjaan dengan posisi duduk. Hasil penilaian postur kerja dapat dilihat pada tabel 1 sebagai berikut.

Tabel 1 Distribusi Pekerja Instalasi Farmasi Berdasarkan Penilaian Postur Kerja di RSUD Kota Madiun, Tahun 2015

\begin{tabular}{lcc}
\hline \multicolumn{1}{c}{ Postur Kerja } & Jumlah & $\mathbf{\%}$ \\
\hline Sedang, skor REBA 4-7 & 2 & 25 \\
\hline $\begin{array}{l}\text { Postur wajar/normal, Skor RULA } \\
\text { 1-2 }\end{array}$ & 2 & 25 \\
\hline $\begin{array}{l}\text { Investigasi lebih lanjut, perubahan } \\
\text { mungkin dibutuhkan, Skor RULA }\end{array}$ & 3 & 37,5 \\
3-4 & & \\
\hline $\begin{array}{l}\text { Investigasi lebih lanjut, perubahan } \\
\text { dilakukan dengan segera, Skor } \\
\text { RULA 5-6 }\end{array}$ & 1 & 12,5 \\
\hline \multicolumn{1}{c}{ TOTAL } & $\mathbf{8}$ & $\mathbf{1 0 0}$ \\
\hline
\end{tabular}


Tabel 2. Distribusi Keluhan Muskoloskeletal Berdasarkan Postur Kerja di RSUD Kota Madiun, Tahun 2015

\begin{tabular}{lccc}
\hline \multicolumn{1}{c}{ Postur Kerja } & $\begin{array}{c}\text { Jumlah } \\
\text { Keluhan }\end{array}$ & $\begin{array}{c}\text { Jumlah } \\
\text { Pekerja }\end{array}$ & \% \\
\hline Sedang, skor REBA 4-7 & 3 & 2 & 25 \\
\hline $\begin{array}{l}\text { Postur wajar/normal, } \\
\text { Skor RULA 1-2 }\end{array}$ & 3 & 2 & 25 \\
\hline $\begin{array}{l}\text { Investigasi lebih lanjut, } \\
\text { perubahan mungkin } \\
\text { dibutuhkan, Skor RULA }\end{array}$ & 5 & 2 & 37,5 \\
3-4 & & & \\
\hline $\begin{array}{l}\text { Investigasi lebih lanjut, } \\
\text { perubahan mungkin } \\
\text { dibutuhkan, Skor RULA }\end{array}$ & 7 & 1 & \\
3-4 & & & \\
\hline $\begin{array}{l}\text { Investigasi lebih lanjut, } \\
\text { perubahan dilakukan } \\
\text { dengan segera, Skor }\end{array}$ & 15 & 1 & 12,5 \\
RULA 5-6 & & & \\
\hline
\end{tabular}

\section{Penilaian Postur Kerja}

Penilaian postur kerja instalasi farmasi dengan menggunakan metode REBA dan RULA dilakukan pada empat bagian kerja instalasi farmasi yaitu bagian administrasi, pergudangan, pelayanan rawat inap dan pelayanan rawat jalan. Berikut analisis dari masing-masing bagian:

\section{Bagian Administrasi}

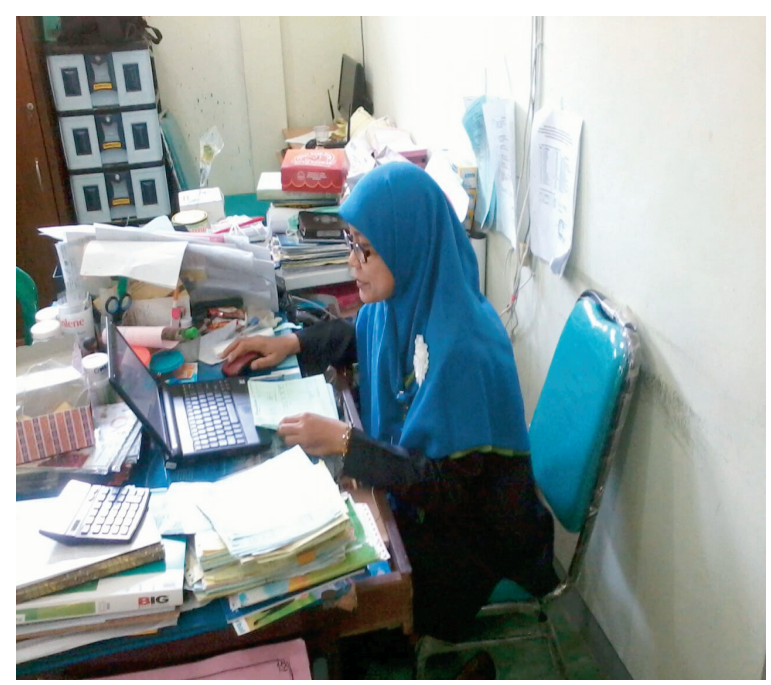

Gambar 1. Contoh Postur Kerja Bagian Administrasi.

Bagian administrasi memiliki pekerjaan untuk membuat data laporan tentang inventori obat dan daftar keluar masuk obat yang berada di instalasi farmasi.

Postur Pekerja administrasi 1 adalah duduk menghadap computer. Penilaian postur RULA adalah sebagai berikut: Posisi lengan atas membentuk sudut $\leq 40^{\circ}$ diberi skor +2 , lengan bawah membentuk sudut $\geq 90^{\circ}$ diberi skor +2 , pergelangan tangan membentuk sudut $\leq 15^{\circ}$ diberi skor +2 , pergelangan tangan memutar kurang dari setengah diberi skor +1 . Nilai tabel A adalah 3

Posisi leher menunduk ke bawah membentuk sudut $\leq 20^{\circ}$ diberi skor +2 , posisi badan membungkuk ke bawah membentuk sudut $\leq 20^{\circ}$ diberi skor +2 , posisi kaki terdapat penyangga maka diberi nilai +1 . Maka nilai untuk tabel $\mathrm{B}$ adalah 2 . Nilai tabel A dan tabel B kemudian dimasukkan ke dalam tabel $\mathrm{C}$, maka nilai tabel $\mathrm{C}$ adalah 3 (Investigasi lebih lanjut, perubahan mungkin dibutuhkan).

Pekerja bagian administrasi 2, postur kerja adalah duduk. Penilaian postur RULA yang didapatkan adalah sebagai berikut: Penilaian postur RULA yang didapatkan adalah sebagai berikut: Posisi lengan atas diberi skor +1 , lengan bawah diberi skor +2 , pergelangan tangan diberi skor +2 , pergelangan tangan memutar kurang dari setengah diberi skor +1 . Nilai tabel A adalah 2 .

Penilaian posisi leher diberi skor +2 , posisi badan diberi skor +2 , posisi kaki terdapat penyangga maka diberi nilai +1 . Maka nilai untuk tabel $\mathrm{B}$ adalah 2. Nilai tabel A dan tabel B kemudian dimasukkan ke dalam tabel $\mathrm{C}$, maka nilai tabel $\mathrm{C}$ adalah 2 (postur yang bisa diterima).

\section{Bagian Pergudangan}

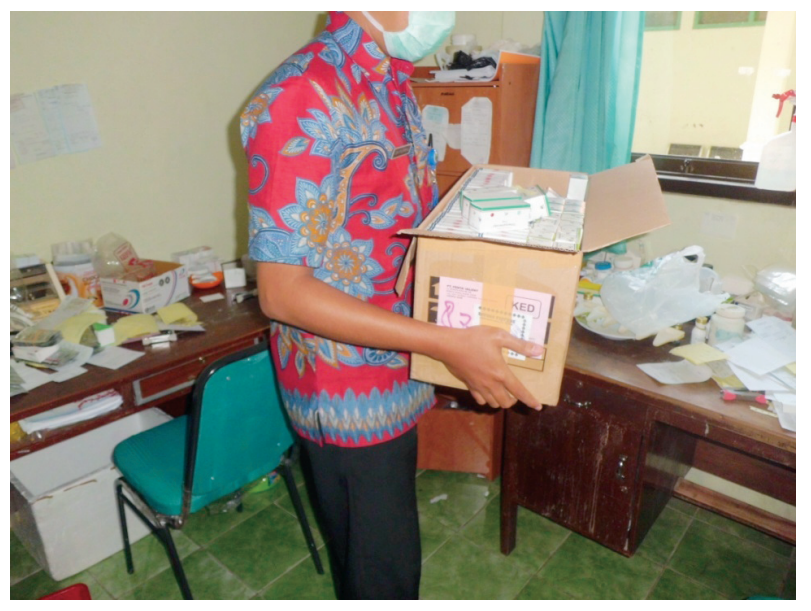

Gambar 2. Contoh Postur Kerja Bagian Pergudangan. 
Bagian pergudangan memiliki tugas untuk mengambil kotak obat dari gudang utama ke gudang instalasi dan kemudian mensortir obat-obat tersebut.

Penilaian postur pekerja 1 menggunakan metode REBA, Postur leher menunduk $\leq 20^{\circ}$ diberi skor +1 , posisi kaki lurus diberi skor +1 , posisi badan tegak lurus diberi skor +1 . Skor dimasukkan pada tabel A, nilai tabel A adalah 1.

Pergelangan tangan pada posisi $\geq 15^{\circ}$ diberi skor +2 dan kemudian tangan memutar/menekuk ke kanan atau kiri diberi skor tambahan +1 , posisi lengan bawah membentuk sudut $\leq 45^{\circ}$ diberi skor +1 , lengan atas membentuk sudut $\geq 45^{\circ}$ diberi skor +3 . Skor tersebut kemudian dimasukkan pada tabel B, nilai tabel B adalah 5 .

Nilai tabel A dan tabel B kemudian dimasukkan pada tabel C. Hasil nilai tabel $\mathrm{C}$ adalah 4 (risiko sedang).

Penilaian postur pekerja 2 menggunakan metode REBA, Postur leher diberi skor +1 , posisi kaki lurus diberi skor +1 , posisi badan tegak lurus diberi skor +1 . Skor dimasukkan pada tabel A, nilai tabel A adalah 1 .

Pergelangan tangan diberi skor +2 dan kemudian tangan memutar/menekuk ke kanan atau kiri diberi skor tambahan +1 , posisi lengan bawah diberi skor +1 , lengan atas diberi skor +3 . Skor tersebut kemudian dimasukkan pada tabel $\mathrm{B}$, nilai tabel B adalah 5 .

Nilai tabel A dan tabe B kemudian dimasukkan pada tabel C. Hasil nilai tabel $\mathrm{C}$ adalah 4 (risiko sedang).

\section{Bagian Pelayanan Rawat Jalan}

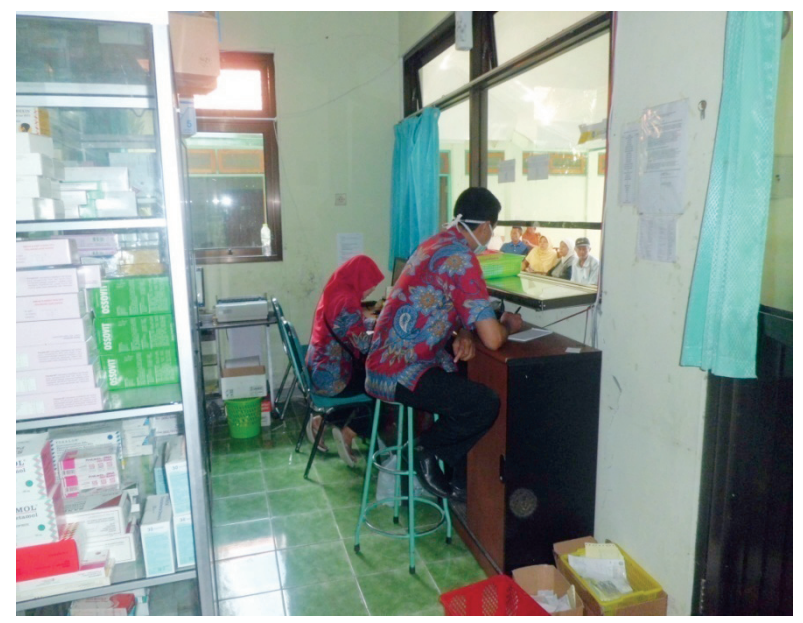

Gambar 3. Contoh Postur Kerja Bagian Rawat Jalan.
Pelayanan rawat jalan bertugas untuk melayani resep obat untuk pasien yang akan dibawa pulang.

Penilaian postur dengan menggunakan metode RULA. Posisi lengan atas membentuk sudut $\leq 45^{\circ}$ diberi skor +2 , posisi lengan bawah membentuk sudut $\leq 100^{\circ}$ diberi skor +1 , posisi pergelangan tangan membentuk sudut $\leq 15^{\circ}$ diberi skor +2 , pergelangan tangan memutar kurang dari setengah diberi nilai +1 . Skor kemudian dimasukkan pada tabel A, skor tabel A adalah 3 .

Posisi leher membentuk sudut $\leq 20^{\circ}$ diberi skor +2 , posisi badan membungkuk ke depan $\leq 60$ diberi skor +3 , posisi kaki ada penyangga skor +1 . Skor kemudian dimasukkan pada tabel $\mathrm{B}$, nilai dari tabel B adalah 4 .

Skor tabel A dan tabel B kemudian dimasukkan pada tabel $\mathrm{C}$, tabel $\mathrm{C}$ menghasilkan skor 4 (Investigasi lebih lanjut, perubahaan mungkin dibutuhkan).

Pekerja bagian rawat jalan 2, postur kerja adalah duduk. Penilaian postur RULA yang didapatkan adalah sebagai berikut: Posisi lengan atas diberi skor +2 , lengan bawah diberi skor +2 , pergelangan tangan diberi skor +2 , pergelangan tangan memutar kurang dari setengah diberi skor +1 . Nilai tabel A adalah 3 .

Penilaian posisi leher diberi skor +2 , posisi badan diberi skor +2 , posisi kaki terdapat penyangga maka diberi nilai +1 . Maka nilai untuk tabel $\mathrm{B}$ adalah 2. Nilai tabel A dan tabel B kemudian dimasukkan ke dalam tabel $\mathrm{C}$, maka nilai tabel $\mathrm{C}$ adalah 3 (Investigasi lebih lanjut, perubahan mungkin dibutuhkan).

\section{Bagian Pelayanan Rawat Inap}

Pelayanan rawat inap bertugas untuk meracik resep bagi pasien yang dirawat inap di rumah sakit.

Penilaian postur dengan menggunakan metode RULA. Posisi lengan atas membentuk sudut $\leq 20^{\circ}$ diberi skor +1 , posisi lengan bawah membentuk sudut $\geq 100^{\circ}$ diberi skor +2 , posisi pergelangan tangan membentuk sudut $\leq 15^{\circ}$ diberi skor +2 , pergelangan tangan memutar kurang dari setengah diberi nilai +1 . Skor kemudian dimasukkan pada tabel A, skor tabel A adalah 2.

Posisi leher membentuk sudut $\leq 20^{\circ}$ diberi skor +2 , posisi badan membungkuk ke depan $\leq 20$ diberi skor +2 , posisi kaki ada penyangga skor +1 . Skor kemudian dimasukkan pada tabel B, nilai dari tabel B adalah 2.

Skor tabel A dan tabel B kemudian dimasukkan pada tabel $\mathrm{C}$, hasil dari tabel $\mathrm{C}$ adalah 2 (postur yang bisa diterima). 
Pekerja bagian rawat inap, postur kerja adalah duduk. Penilaian postur RULA yang didapatkan adalah sebagai berikut: Posisi lengan atas diberi skor +2 , lengan bawah diberi skor +2 , pergelangan tangan diberi skor +2 , pergelangan tangan memutar kurang dari setengah diberi skor +1 . Nilai tabel A adalah 3 .

Penilaian posisi leher diberi skor +2 , posisi badan diberi skor +2 , posisi kaki terdapat penyangga maka diberi nilai +1 . Maka nilai untuk tabel $B$ adalah 2. Nilai tabel A dan tabel B kemudian dimasukkan ke dalam tabel C, maka nilai tabel $\mathrm{C}$ adalah 3 (Investigasi lebih lanjut, perubahan mungkin dibutuhkan).

\section{Penilaian Keluhan Muskoloskeletal}

Keluhan muskoloskeletal diperoleh dari pengisian Nordic Body Map oleh responden. Hasil penilaian Nordic Body Map mengindikasikan sebanyak 8 orang atau sebanyak $100 \%$ pekerja mengalami keluhan muskoloskeletal. Data hasil keluhan muskoloskelatal responden dapat dilihat pada tabel 4 .

Berdasarkan Tabel 3 diketahui bahwa keluhan muskoloskeletal yang sering terjadi pada pekerja instalasi farmasi terdapat pada bagian pinggang $(87,5 \%)$, pinggul $(62,5 \%)$, leher bagian atas dan bagian bawah (50\%), dan bahu kiri $(37,5 \%)$.

Tabel 3. Distribusi Data Keluhan Muskoloskeletal Pada Pekerja Instalasi Farmasi RSUD Kota Madiun Tahun 2015

\begin{tabular}{|c|c|c|c|c|c|c|c|}
\hline \multirow{3}{*}{ No } & \multirow{3}{*}{ Otot Skeletal } & \multicolumn{4}{|c|}{ Keluhan MSDs } & \multirow{2}{*}{\multicolumn{2}{|c|}{ Total }} \\
\hline & & \multicolumn{2}{|c|}{ Ya } & \multicolumn{2}{|c|}{ Tidak } & & \\
\hline & & $\mathbf{n}$ & $\%$ & $\mathbf{N}$ & $\%$ & $\mathbf{n}$ & $\%$ \\
\hline 0 & Leher bagian atas & 4 & 50 & 4 & 50 & 8 & 100 \\
\hline 1 & Leher bagian bawah & 4 & 50 & 4 & 50 & 8 & 100 \\
\hline 2 & Bahu kiri & 3 & 37,5 & 5 & 62,5 & 8 & 100 \\
\hline 3 & Bahu kanan & 2 & 25 & 6 & 75 & 8 & 100 \\
\hline 4 & Lengan atas kiri & 0 & 0 & 8 & 100 & 8 & 100 \\
\hline 5 & Punggung & 2 & 25 & 6 & 75 & 8 & 100 \\
\hline 6 & Lengan atas kanan & 0 & 0 & 8 & 100 & 8 & 100 \\
\hline 7 & Pinggang & 7 & 87.5 & 1 & 12,5 & 8 & 100 \\
\hline 8 & Pinggul & 5 & 62,5 & 3 & 37,5 & 8 & 100 \\
\hline 9 & Pantat & 1 & 12,5 & 7 & 87,5 & 8 & 100 \\
\hline 10 & Siku kiri & 0 & 0 & 8 & 100 & 8 & 100 \\
\hline 11 & Siku kanan & 0 & 0 & 8 & 100 & 8 & 100 \\
\hline 12 & Lengan bawah kiri & 1 & 12,5 & 7 & 87,5 & 8 & 100 \\
\hline 13 & Lengan bawah kanan & 1 & 12,5 & 7 & 87,5 & 8 & 100 \\
\hline 14 & Pergelangan tangan kiri & 1 & 12,5 & 7 & 87,5 & 8 & 100 \\
\hline 15 & Pergelangan tangan kanan & 1 & 12,5 & 7 & 87,5 & 8 & 100 \\
\hline 16 & Tangan kiri & 0 & 0 & 8 & 100 & 8 & 100 \\
\hline 17 & Tangan kanan & 0 & 0 & 8 & 100 & 8 & 100 \\
\hline 18 & Paha kiri & 1 & 12,5 & 7 & 87,5 & 8 & 100 \\
\hline 19 & Paha kanan & 1 & 12,5 & 7 & 87,5 & 8 & 100 \\
\hline 20 & Lutut kiri & 1 & 12,5 & 7 & 87,5 & 8 & 100 \\
\hline 21 & Lutut kanan & 1 & 12,5 & 7 & 87,5 & 8 & 100 \\
\hline 22 & Betis kiri & 2 & 25 & 6 & 75 & 8 & 100 \\
\hline 23 & Betis kanan & 2 & 25 & 6 & 75 & 8 & 100 \\
\hline 24 & Pergelangan kaki kiri & 1 & 12,5 & 7 & 87,5 & 8 & 100 \\
\hline 25 & Pergelangan kaki kanan & 1 & 12,5 & 7 & 87,5 & 8 & 100 \\
\hline 26 & Kaki kiri & 1 & 12,5 & 7 & 87,5 & 8 & 100 \\
\hline 27 & Kaki kanan & 1 & 12,5 & 7 & 87,5 & 8 & 100 \\
\hline
\end{tabular}




\section{PEMBAHASAN}

Penilaian postur kerja dilakukan dengan menggunakan dua metode yaitu dengan yang pertama dengan menggunakan metode REBA (Rapid Entire Body Assessment) dan kedua menggunakan metode RULA (Rapid Upper Limb Assessment). Penilaian keluhan muskoloskeletal dengan menggunakan Nordic Body Map

Metode REBA diperkenalkan oleh Sue Hignett dan Lynn Mc Atemney dalam jurnal Applied Ergonomic pada tahun 2000. Metode REBA memungkinkan dilakukan suatu analisis secara bersama dari posisi pada anggota tubuh bagian atas, badan, leher dan kaki. Metode REBA juga mendefinisikan faktor lain selain postur tubuh seperti beban atau gaya yang dilakukan, cara memegang, jenis aktivitas otot yang dilakukan pekerja. Metode REBA membagi segmen tubuh menjadi dua bagian, bagian A terdiri dari badan, leher, dan kaki. Sementara bagian B meliputi lengan atas, lengan bawah dan pegelangan tangan. Grand skor REBA dibagi menjadi 5 action level yaitu: action level 0 dengan skor REBA 1 level risiko bisa diabaikan, action level 1 dengan skor REBA 2-3 level risiko rendah, action level 2 dengan skor REBA 4-7 level risiko sedang action level 3 dengan skor REBA 8-10 level risiko tinggi, action level 4 dengan skor REBA 11-15 level risiko sangat tinggi (Tarwaka, 2010).

Metode RULA pertama kali dikembangkan oleh Lynn Mc Atemney dan Nigel Corlen, E. Metode RULA prinsipnya hampir sama dengan REBA dan OWAS. Metode RULA digunakan untuk mengestimasi postur tubuh, khususnya pada tubuh bagian atas. Metode Pengukuran RULA pada prinsipnya adalah mengukur sudut yang dibentuk oleh anggota tubuh pada saat melakukan pekerjaan. Penilaian dipisah menjadi dua bagian yaitu grup A dan B. Grup A meliputi lengan atas, lengan bawah dan pergelangan tangan. Grup B meliputi kaki badan dan leher. Grand skor RULA dibagi menjadi 4 bagian yaitu: skor $1-2=$ postur tubuh bisa diterima, skor 3-4 = investigasi lebih lanjut, perubahan mungkin diperlukan, skor 5-6 = investigasi lebih lanjut, perubahan dengan segera, skor $7=$ investigasi dan penerapan perubahan (Tarwaka, 2010).

Dari hasil penelitian dapat diketahui bahwa pekerja dengan skor RULA 1-2 yang merupakan postur wajar sebanyak $(25 \%)$, pekerja mendapatkan skor RULA 3-4 yang berarti perlu investigasi lebih lanjut dan perubahan mungkin dibutuhkan sebanyak (37,5\%), pekerja dengan skor RULA 5-6 yang berarti investigasi lebih lanjut, perubahan dilakukan dengan segera sebanyak (12,5\%). Skor REBA 4-7 sebanyak 25\% (level risiko sedang).

Metode Nordic Body Map merupakan metode yang digunakan untuk menilai tingkat keparahan atas terjadinya gangguan otot skeletal, penilaian metode Nordic Body Map sangat subjektif, yang berarti tingkat keberhasilan pengaplikasian tergantung dari situasi dan kondisi yang dialami oleh pekerja saat dilakukan penilaian, dan juga tergantung pada keahlian observer. Dalam penerapannya, Nordic Body Map menggunakan lembar kerja tubuh yang sangat sederhana, mudah dipahami, berbiaya murah, penggunaan waktu yang singkat untuk penilaian per individu. Observer dapat langsung bertanya pada responden pada bagian mana yang mengalami keluhan rasa sakit.

Penilaian Nordic Body Map meliputi 28 bagian otot skeletal dimulai dari otot bagian atas yaitu leher sampai dengan bagian paling bawah yaitu otot kaki. Pada skala data nominal dapat dilakukan dengan menggunakan dua jawaban yaitu Ya (ada keluhan rasa sakit pada otot skeletal) dan Tidak (tidak ada keluhan pada otot skeletal)

Dari hasil penelitian diketahui bahwa keluhan yang banyak dialami pekerja berdasarkan Nordic Body Map yaitu pada pinggang $(87,5 \%)$, pinggul $(62,5 \%)$, leher bagian atas $(50 \%)$, leher bagian bawah (50\%), bahu kiri (37,5\%), bahu kanan (25\%), punggung $(25 \%)$, betis kiri $(25 \%)$ dan betis kanan (25\%).

Hasil penelitian menunjukkan distribusi data keluhan muskoloskeletal berdasarkan postur kerja sebanyak 2 orang pekerja dengan skor REBA 4-7 mengalami jumlah keluhan pada 3 bagian tubuh, 2 orang pekerja dengan skor RULA 1-2 mengalami keluhan pada 3 bagian tubuh, 3 orang pekerja dengan skor RULA 3-4 mengalami 3-7 keluhan pada bagian tubuhnya, dan 1 orang pekerja dengan skor RULA 5-6 mengalami 15 keluhan pada bagian tubuhnya.

Hal ini sesuai dengan penelitian Arfiasari (2014) yang menyatakan bahwa ada hubungan yang cukup kuat antara postur kerja dan keluhan muskoloskeletal. Hal ini disebabkan oleh faktor peralatan kerja yang tidak sesuai sehingga mempengaruhi postur kerja pekerja yang kemudian juga berpengaruh terhadap keluhan muskoloskeletal.

Tarwaka (2010), menyatakan bahwa pada umumnya keluhan otot skeletal mulai dirasakan pada usia kerja, yaitu usia 25-65 tahun. Keluhan pertama biasanya dirasakan pada umur 35 tahun dan tingkat keluhan akan terus meningkat sejalan dengan 
bertambahnya umur. Hal ini terjadi karena pada umur setengah baya, kekuatan dan ketahanan otot mulai menurun sehingga risiko terjadinya keluhan otot meningkat.

Dari hasil penelitian diketahui bahwa komposisi pekerja berdasarkan usia yaitu pekerja berusia $<35$ tahun merupakan mayoritas kelompok usia dengan distribusi sebanyak $62,5 \%$, sedangkan kelompok usia $\geq 35$ tahun dengan distribusi sebanyak $37,5 \%$. Berdasarkan data penelitian semua pekerja mengalami keluhan muskoloskeletal. Berdasarkan hasil penelitian jumlah keluhan muskoloskeletal tertinggi terdapat pada pekerja dengan kelompok usia $<35$ tahun sebanyak 15 keluhan.

Hasil penelitian ini tidak sesuai dengan penelitian Bukhori (2010), yang menunjukkan bahwa ada hubungan antara keluhan muskoloskeletal dengan usia, pekerja dengan usia sama dengan atau lebih dari 35 tahun memiliki risiko keluhan yang lebih tinggi dibanding kelompok usia kurang dari 35 tahun.

Pada pekerja yang memiliki keluhan sebanyak 15 pada usia kurang dari 35 tahun memiliki faktor lain yang menyebabkan ketidaksesuaian dengan hasil penelitian lain yaitu waktu istirahat pekerja tersebut kurang dari 7 jam per harinya. Menurut Nurliah (2011), semakin kurang jam istirahat dapat menyebabkan meningkatnya risiko keluhan muskoloskeletal.

Kekuatan otot wanita hanya sekitar dua pertiga dari kekuatan otot pria, sehingga daya tahan otot pria pun lebih tinggi dibandingkan dengan wanita. Menurut Betti'e dkk (1989), dalam Tarwaka (2010), rerata kekuatan otot wanita kurang lebih hanya $60 \%$ dari kekuatan otot pria, khususnya untuk otot lengan, punggung dan kaki. Hal ini diperkuat oleh hasil penelitian Chiang dkk. (1993), Bernard dkk. (1994), Hales dkk. (1994), dan Jonson (1994), dalam Tarwaka (2010), yang menyatakan bahwa perbandingan keluhan otot antara pria dan wanita adalah 1: 3. Dari uraian tersebut diatas, maka jenis kelamin perlu dipertimbangkan dalam mendesain beban tugas.

Dari hasil penelitian dapat diketahui bahwa komposisi pekerja instalasi farmasi berdasarkan jenis kelamin yaitu mayoritas merupakan pekerja wanita dengan persentase $75 \%$, sedangkan pekerja pria terdapat $25 \%$. Berdasarkan hasil penelitian jumlah keluhan muskoloskeletal berdasarkan jenis kelamin paling banyak terdapat pada wanita dengan jumlah keluhan 15 dan pada pria terdapat 3 keluhan.
Hasil penelitian ini sejalan dengan Wijnhoven dkk (2006), dalam penelitiannya menunjukkan bahwa tingkat prevalensi nyeri muskoloskeletal yang lebih tinggi bagi perempuan daripada lakilaki. Untuk nyeri muskoloskeletal di setiap lokasi, $39 \%$ pria dan $45 \%$ wanita dilaporkan keluhan kronis. Hasil penelitian ini juga sesuai dengan Sultan dkk (2014), yang menunjukkan bahwa ada hubungan antara jenis kelamin dengan keluhan muskoloskeletal pada pekerja. Hal ini sebagai akibat pengaruh hormonal yang berbeda antara pria dan wanita. Hormon kewanitaan menyebabkan fisik wanita lebih halus, pertumbuhan kelengkapan tubuh kewanitaan dan terdapat jaringan lemak di tempattempat pada tubuh yang pria tidak memilikinya.

Dari hasil penelitian dapat diketahui bahwa komposisi pekerja instalasi farmasi berdasarkan tingkat pendidikan yaitu mayoritas berpendidikan terakhir SMA/setara dengan persentase $75 \%$ yaitu 6 orang pekerja, sedangkan pekerja yang berpendidikan perguruan tinggi terdapat 2 orang atau sebesar $25 \%$. Jumlah keluhan terbanyak di alami pada pekerja dengan tingkat pendidikan SMA dengan jumlah keluhan 15 dan paling sedikit pada pekerja dengan tingkat pendidikan perguruan tinggi dengan jumlah keluhan 3 .

Sejalan dengan pernyataan OSHA Eropa, tingkat pengetahuan pekerja tentang masalah yang terkait dengan penyakit akibat kerja dapat menurunkan risiko terjadinya penyakit muskoloskeletal. Lebih lanjut dalam pekerjaan tertentu pelatihan tentang metode kerja yang benar dapat menekan beban kerja yang berarti mengurangi risiko penyakit akibat kerja dan kecelakaan kerja.

Dari hasil penelitian diketahui bahwa tidak ada pekerja yang memiliki kebiasaan merokok, tetapi faktor merokok merupakan salah satu faktor yang mempengaruhi keluhan muskoloskeletal. Menurut Bosshuizen dkk (1993) dalam Tarwaka (2010), menemukan hubungan yang signifikan antara kebiasaan merokok dengan keluhan otot pinggang, khususnya untuk pekerjaan yang memerlukan pengerahan otot. Hal ini sebenarnya terkait erat dengan kondisi kesegaran tubuh seseorang. Kebiasaan merokok akan menurunkan kapasitas paru sehingga kemampuan untuk mengonsumsi oksigen menurun dan sebagai akibatnya tingkat kesegaran tubuh juga menurun. Apabila yang bersangkutan harus melakukan tugas yang menuntut pengerahan tenaga maka akan mempercepat terjadinya kelelahan karena kandungan oksigen dalam darah, pembakaran 
karbohidrat akan terhambat, terjadi penumpukan asam laktat, dan akhirnya timbul rasa nyeri otot.

Troup, dkk (1987) dalam Bernard (1997), menyatakan bahwa beberapa hasil penelitian menunjukkan bahwa perokok lebih memiliki kemungkinan menderita masalah punggung daripada bukan perokok. Hubungan merokok dengan keluhan MSDs disebabkan karena batuk yang meningkatkan tekanan pada perut dan menimbulkan ketegangan pada tulang belakang atau punggung. Pendapat yang serupa tentang mekanisme merokok dengan keluhan MSDs adalah jumlah nikotin yang terserap masuk bisa mengurangi aliran darah ke jaringan. Selain itu merokok dapat pula menyebabkan kekurangan kandungan mineral dalam tulang yang menyebabkan nyeri atau kerusakan pada tulang (Bernard, 1997).

Tarwaka (2010), menyatakan pengaruh yang relatif kecil antara berat badan, tinggi badan, dan massa tubuh dengan kejadian keluhan muskoloskeletal. Tubuh yang tinggi sering menderita keluhan sakit punggung tapi tubuh yang tinggi tidak mempunyai pengaruh terhadap keluhan leher, bahu, dan pergelangan tangan. Tubuh yang tinggi mempunyai bentuk tulang yang langsing sehingga secara biomekanik rentan terhadap beban tekan dan rentan terhadap tekukan sehingga tinggi badan yang tinggi memiliki risiko lebih tinggi terhadap keluhan muskuloskeletal.

Dari hasil penelitian diketahui bahwa komposisi pekerja instalasi farmasi berdasarkan Indeks Massa Tubuh yaitu mayoritas memiliki berat badan normal dengan persentase $75 \%$, sedangkan pekerja dengan tingkat berat badan lebih sebesar $25 \%$. Jumlah keluhan tertinggi terdapat pada pekerja dengan berat badan normal, dan jumlah keluhan terendah juga terdapat pada pekerja dengan berat badan normal.

Sejalan dengan penelitian Laura (2013), yang menyatakan kaitan indeks massa tubuh dengan gejala muskuloskeletal relatif kecil. Selanjutnya, Mengindahkan beban kerja fisik yang tinggi atau rendah. Dibanding dengan karyawan dengan berat badan normal, karyawan obesitas memiliki risiko lebih tinggi untuk mengembangkan gejala muskuloskeletal.

Cady, dkk (1979) dalam Tarwaka (2010), menyatakan bahwa untuk tingkat kesegaran tubuh rendah maka risiko terjadi keluhan muskuloskeletal sebesar 7,1\%. Tingkat kesegaran tubuh sedang risiko terjadi keluhan muskuloskeletal sebesar 3,2\% dan tingkat kesegaran tubuh tinggi risiko terjadi keluhan muskuloskeletal sebesar 0,8\%. Batti'e dkk (1989) dalam Tarwaka (2010), memaparkan hasil penelitian terhadap para penerbang menunjukkan bahwa kelompok penerbang dengan tingkat kesegaran tubuh yang tinggi mempunyai risiko yang sangat kecil terhadap risiko cedera otot.

Dari hasil penelitian dapat diketahui bahwa komposisi pekerja instalasi farmasi berdasarkan kebiasaan berolahraga yaitu mayoritas olahraga sekali dalam seminggu dengan persentase $62,5 \%$ yaitu 5 orang pekerja, pekerja yang tidak berolahraga memiliki persentase $25 \%$ atau 2 orang, sedangkan yang berolahraga dua kali dalam seminggu terdapat $12,5 \%$ atau 1 orang jumlah keluhan muskoloskeletal terbanyak berdasarkan kebiasaan olahraga terdapat pada pekerja yang tidak berolahraga sebanyak 15 keluhan. Dan jumlah keluhan paling sedikit terdapat pada pekerja yang berolahraga dua kali seminggu.

Hasil penelitian ini sejalan dengan penelitian Handayani (2011), yang menyatakan bahwa ada hubungan antara kebiasaan olahraga dengan keluhan muskoloskeletal, pekerja dengan kebiasaan olahraga yang kurang mempunyai kecenderungan memiliki keluhan muskoloskeletal yang lebih tinggi. Dapat disimpulkan bahwa kebiasaan olahraga merupakan salah satu faktor yang mempengaruhi keluhan muskoloskeletal.

Pada umumnya, keluhan otot lebih jarang ditemukan pada seseorang yang dalam aktivitas yang mempunyai cukup waktu untuk istirahat. Sebaliknya bagi orang yang melakukan aktivitas namun tidak mempunyai waktu yang cukup untuk istirahat, hampir dipastikan akan terjadi kelelahan otot. Tingkat kesegaran tubuh yang rendah akan mempertinggi risiko terjadinya keluhan otot. Keluhan otot akan meningkat sejalan dengan bertambahnya aktivitas fisik (Tarwaka, 2010).

Diketahui bahwa komposisi pekerja instalasi farmasi berdasarkan waktu istirahat yaitu mayoritas memiliki waktu istirahat kurang dari 7 jam/hari dengan persentase $75 \%$ yaitu 6 orang pekerja, sedangkan pekerja dengan waktu istirahat lebih dari 7 jam/hari terdapat 2 orang atau sebesar $25 \%$ jumlah keluhan muskoloskeletal terbanyak berdasarkan waktu istirahat terdapat pada pekerja dengan waktu istirahat $<7$ jam sebanyak 15 keluhan.

Hasil penelitian ini sesuai dengan penelitian Nurliah (2011), yang menyatakan bahwa ada hubungan antara jumlah jam istirahat dengan keluhan muskoloskeletal, semakin kurang jam istirahat dapat menyebabkan meningkatnya risiko keluhan muskoloskeletal. Hasil penelitian ini juga sesuai dengan Courtiol (2010), yang menyatakan bahwa keluhan otot jarang ditemukan pada orang 
dengan istirahat yang cukup yaitu sekitar tujuh jam.

\section{SIMPULAN}

Simpulan yang dapat diambil bersadarkan penelitian ini adalah:

Hasil Identifikasi berdasarkan postur kerja dengan metode REBA dan RULA pada pekerja instalasi farmasi RSUD Kota Madiun didapatkan bahwa mayoritas pekerja memiliki masalah pada postur kerjanya.

Keluhan muskoloskeletal paling sering terjadi pada pekerja instalasi farmasi RSUD Kota Madiun adalah pada bagian pinggang.

\section{DAFTAR PUSTAKA}

Arfiasari, A. 2014. Hubungan Postur Kerja dengan Keluhan Muskoloskeletal dan Produktivitas Kerja pada Pekerja Bagian Pengepakan di PT Djitoe Indonesia Tobako. Universitas Muhammadiyah Surakarta.

Bernard, B.P, Anderson, V.P, Burt, S.E. 1997. Muscoloskeletal Disorders and Workplace Factors: A Chemical Review of Epidemiologic Evidence for Work-Related MSDs of Neck, Upper Extrimity and Low Back. U.S Department of Health and Human Services, PH Service for Disease Control and Prevention, National Institute for Occupational Safety And Health.

Buckley, P. MusculoSkeletal Disorder in Great Britain. http://www.hse.gov.uk/statistics/causdis/ musculoskeletal/msd.pdf (sitasi 8 Januari 2015)

Bukhori, E. 2010. Hubungan Faktor Risiko Pekerjaan dengan Terjadinya Keluhan Muskoloskeletal Disorder pada Tukang Angkut Penambang Emas di Kecamata Cilongtang Kabupaten Lebk. Skripsi. Jakarta; Universitas Islam Negeri Syarif Hidayatullah: 60-66.

Courtiol, M. 2010. The natural health benefit of napping.http://www.natural-health-journals. com/908/the-natural-health-benefits-ofnapping\#more-908 (sitasi 15 Januari 2015)

Departemen Kesehatan RI. 2008. Profil Masalah Kesehatan Tahun 2008. Jakarta.

Handayani, W. 2011. Faktor-Faktor yang Berhubungan dengan Keluhan Muskoloskeletal Disorders Pada Pekerja Bagian Polishing PT. Surya Toto Indonesia. Tbk Tanggerang. Skripsi. Jakarta, Universitas Islam Negeri Hidayatullah: 120-138.

Istighfaniar, Kun. 2016. Analisis Postur Kerja dan Keluhan Muskoloskeletal pada Pekerja Instalasi Farmasi di RSUD Kota Madiun. Skripsi. Surabaya, Fakultas Kesehatan Masyarakat Universitas Airlangga.

Laura, V. 2013. The relation between body mass index and musculoskeletal symptoms in the working population. http://www.biomedcentral.com/14712474/14/238 (sitasi 2 April 2015).

Nurliah, A. 2012. Analisis Risiko Muscoloskeletal Disorders (MSDs) Pada Operator Forklift di PT LLI. Tesis. Depok; Universitas Indonesia: 71-74.

Sultan Bedu., H.H, Russeng., S.S, Rahim, M.R. 2014. Faktor yang Berhubungan dengan Gangguan Muskoloskeletal pada Cleaning Service di RSUP DR. Wahidin SudiroHusodo Makasar. Universitas Hasanudin.

Tarwaka. 2010. Ergonomi Industri. Surakarta: Harapan Press Solo.

WHO. 2003. Preventing Muscoloskeletal Disorders in the Workplace. http://apps. who.int/iris/bitstrea m/10665/42651/1/924159053X.pdf?ua=1 (sitasi 5 Januari 2015).

Wijnhoven HA., de Vet HC., Picavet HS. 2006. Prevalence of musculoskeletal disorders is systematically higher in women than in men. http://journals.lww.com/clinicalpain/pages/ articleviewer.aspx? year $=2006 \&$ issue $=10000 \&$ art icle $=00008 \&$ type $=$ abstract (sitasi 2 April 2015). 